\title{
USAHA MENINGKATKAN MINAT BACA MAHASISWA MELALUI PELAYANAN PRIMA DI PERPUSTAKAAN PERGURUAN TINGGI
}

\author{
RetnoSusilowati \\ Institut Agama Islam Negeri Kudus, Jawa Tengah, Indonesia \\ Luqyana02@gmail.com
}

\begin{abstract}
Excellent service in the library is very urgent, because the success of the library is very dependent on the librarian. The attractiveness of the library depends on the excellent service carried out by the librarian. This service can be in the form of the physical form provided and the service of the library staff. Physically, the library provides modern technology, such as the internet, the use of smart phones, computer programs and the development of information so quickly obtained. Therefore, library must provide online library, so it can be facilitate the information process. If the library can carry out excellent service, then there will be no doubt that the enthusiasm of students to read is higher, so that it can support the studying process. The information that students will get faster, so that the studying process will also be faster to complete.
\end{abstract}

Keywords: excellent service, library, reading interest. 


\begin{abstract}
Abstrak
Pelayanan prima di perpustakaan merupakan hal yang sangat urgen dilakukan, karena keberhasilan perpustakaan sangat bergantung pada pemustakanya. Daya tarik perpustakaan tergantung pada pelayanan prima yang dilakukan oleh pihak perpustakaan. Pelayanan ini bisa berupa bentuk fisik yang disediakan dan pelayanan petugas perpustakaan. Secara fisik perpustakaan menyediakan teknologi serba canggih, yaitu berkembangnya internet, penggunaan handphone smart, program komputer maka perkembangan informasi begitu cepat didapat. Oleh karena itu perpustakaan harus menyediakan perpustakaan online, sehingga dapat memperlancar proses informasi. Apabila perpustakaan bisa melaksanakan pelayanan prima, maka dapat menunjang antusiasme mahasiswa sehingga minat membaca semakin tinggi, pada akhirnya dapat mendukung dalam proses perkuliahan. Informasi yang akan didapat mahasiswa semakin cepat, sehingga tugas-tugas mata kuliah juga akan semakin cepat pula untuk diselesaikan.
\end{abstract}

Kata Kunci: Pelayanan prima, perpustakaan, minat membaca.

\title{
A. Pendahuluan
}

Pelayanan prima di perpustakaan merupakan hal yang sangat urgen dilakukan, karena keberhasilan perpustakaan sangat bergantung pada pemustakanya. Daya tarik perpustakaan tergantung pada pelayanan prima yang dilakukan oleh pihak perpustakaan. Pelayanan ini bisa berupa bentuk fisik yang disediakan dan pelayanan petugas perpustakaan.

Perpustakaan sebagai jendela dunia, maka peran perpustakaan sangat penting di tengah-tengah dunia pendidikan. Pelayanan perpustakaan yang kurang memadai seperti, ruang yang sempit, bau yang kurang sedap,ventilasi udara yang kurang atau pengap, koleksi bukuyang sudah kadaluwarsa dan bau apek, berdebu, bahkan pelayanan para pustakawan yang kurang ramah dan menyenangkan dapat mengurangi semangat para pembaca untuk berkunjung ke perpustakaan. Maka dari itu perlu ada usaha 
yang maksimal untuk menambah minat baca pengunjung dengan pelayanan prima.

Apabila perpustakaan bisa melaksanakan pelayanan prima, maka antusiasme mahasiswa untuk membaca semakin tinggi, sehingga dapat mendukung dalam proses perkuliahan. Informasi yang akan didapat mahasiswa semakin cepat, sehingga tugas-tugas mata kuliah juga akan semakin cepat pula untuk diselesaikan.

\section{B. Pembahasan}

\section{Pengertian Pelayanan Prima}

Excellent service atau disebut juga Pelayanan Prima adalah pelayanan yang sangat baik dan melampaui harapan pemustaka. ${ }^{1}$ Atau dengan kata lainPelayanan prima yaitu melakukan pelayanan sebaik mungkin kepada para pemustaka atau pemustaka sehingga menimbulkan rasa yang puas. Secara umum tujuan pelayanan prima yaitu memberikan pelayanan sehingga bisa memenuhi dan memuaskan para pemustaka sehingga lembaga mendapatkan keuntungan yang maksimal. Manfaat dari pelayanan prima salah satunya untuk meningkatkan kualitas pelayanan lembaga ataupun pemerintah kepada para pemustaka atau masyarakat, serta dapat menjadi acuan untuk pengembangan penyusunan standar pelayanan. Standar pelayanan dapat diartikan sebagai tolak ukur atau patokan yang digunakan untuk melakukan pelayanan dan juga sebagai acuan untuk menilai kualitas suatu pelayanan. Pelayanan disebut prima jika pemustaka sudah merasa puas dan sesuai dengan harapan pemustaka.

\section{Tujuan Pelayanan Prima}

Tujuan Pelayanan Prima adalah memberikan pelayanan yang dapat memberikan kepuasan dan fokus kepada pemustaka. ${ }^{2}$ Ilmu, 2013), 17.

${ }^{1}$ Nina Rahmayanty, Manajemen Pelayanan Prima (Yogyakarta: Graha

${ }^{2}$ Andi Prastowo, Manajemen Perpustakaan Sekolah Profesional (Yogyakarta: Diva Press, 2012), 245. 
Adapun beberapa tujuan pelayanan prima diantaranya sebagai berikut ini:

- Memberikan pelayanan yang berkualitas kepada para pemustakanya.

- Membantu pemustaka untuk mengambil keputusan, supaya membeli barang atau jasa yang ditawarkan.

- Menumbuhkan rasa percaya pemustaka terhadap barang ataupun jasa yang di tawarkan penjual.

- Menumbuhkan kepercayaan dan kepuasan kepada para pemustaka.

- Untuk menghindari terjadinya berbagai macam tuntutan atau aduan dari pemustaka kepada penjual terhadap produk atau jasa yang dijualnya.

- Supaya pemustaka atau pemustaka merasa diperhatikan dan merasa diperlakukan secara baik.

- Untuk menumbuhkan dan mempertahankan loyalitas pemustaka, supaya tetap membeli barang atau jasa yang di jual.

\section{Fungsi Pelayanan Prima}

Adapun beberapa fungsi pelayanan prima diantaranya sebagai berikut ini:

- Untuk melayani pemustaka dengan ramah, tepat dan cepat, sehingga pemustaka merasa puas.

- Untuk menciptakan suasana dimana pemustaka merasa diperhatikan dan dianggap sangat penting bagi lembaga.

- Untuk menciptakan pangsa pasar yang lebih baik lagi terhadap produk ataupun jasa yang di jual.

- Untuk memuaskan pemustaka, supaya tetap menggunakan produk maupun jasa lembaga.

- Untuk menempatkan para pemustaka sebagai mitra bisnis.

- Untuk dapat memenangkan persaingan pasar.

- Dan untuk memberikan keuntungan yang maksimal. 


\section{Konsep Dasar Pelayanan Prima}

Konsep pelayanan prima ada 3 (tiga) macam, berikut ini penjelasan singkatnya:

\section{a. Konsep Sikap / Attitude}

Sikap yang harus dimiliki diantaranya sikap yang ramah, penuh perhatian, dan memiliki rasa bangga terhadap lembaga. Diharapkan para pegawai pada suatu lembaga harus mencerminkan lembaga itu sendiri. Karena para pegawai yang melayani pemustaka akan mencerminkan citra lembaga. Para pemustaka atau pemustaka akan memberikan kesan pertama saat berhubungan langsung dengan orang yang terlibat dalam lembaga tersebut salah satunya yaitu pegawainya yang memberikan pelayanan. Kesuksesan suatu lembaga jasa pelayanan akan sangat tergantung pada orang-orang yang terlibat dalam menjalankan lembaga tersebut. Beberapa sikap yang di harapkan seperti sikap yang memiliki rasa bangga terhadap pekerjaan yang dilakukan, mengabdi kepada pekerjaan yang dilakukan, selalu menjaga citra baik lembaga dan lain-lain. Tentunya pada konsep sikap ini pegawai pelayanan harus memiliki pengetahuan yang berhubungan dengan pekerjaannya, memiliki kemampuan atau keterampilan yang sesuai dengan pekerjaannya, dan bisa berkomunikasi dengan baik. Dan yang harus diperhatikan juga pegawai harus berpenampilan menarik dan sopan sesuai peraturan lembaga. Membaca konsep diatas berarti pustakawan harus bersikap yang baik kepada pengunjung.

\section{b. Konsep Perhatian / Attention}

Saat melakukan pelayanan kepada pemustaka, maka perlu memperhatikan dan mencermati keinginan pemustakanya. Jika pemustaka sudah menunjukan niat untuk membaca, atau meminjam buku maka segera dilayani dan tawarkan bantuan yang dia perlukan sehingga pemustaka merasa diperhatikan, dan keinginannya dapat terpenuhi. Beberapa hal yang perlu diperhatikan dalam konsep ini seperti mengucapkan salam saat memulai pembicaraan, bertanya apa saja yang di inginkan pemustaka, memahami keinginan 
pemustaka, melakukan pelayanan dengan ramah, tepat dan cepat serta harus menempatkan kepentingan pemustaka menjadi yang paling utama, karena pemustaka adalah raja.

\section{c. Konsep tindakan / Action}

Dalam konsep tindakan, misalnya seorang pegawai pada bagian pelayanan harus selalu memperhatikan dan mencermati apa yang menjadi keinginan pemustaka. Beberapa bentuk pelayanan pada konsep ini misalnya seperti mencatat pesanan yang di inginkan pemustaka, menegaskan atau mengecek kembali yang di pesan pemustaka, menyelesaikan transaksi pesanan pemustaka, dan bisanya jika sudah melayani mengucapkan terimakasih kepada pemustaka.

\section{Karakteristik Kualitas dari Pelayanan Prima}

Adapun karakteristik kualitas yang dimiliki pelayanan prima diantaranya sebagai berikut ini:

\section{a. Penampilan}

Penampilan sangat di perlukan untuk melakukan pelayan prima kepada para pemustaka, karena dengan penampilan yang baik dapat meyakinkan pemustaka saat memberikan pelayanan. Misalnya sebagai resepsionis maka harus memiliki tutur kata yang baik, berpenampilan yang menarik, memiliki tubuh yang porposional, dan lain-lain.

\section{b. Kesopanan dan Ramah}

Pegawai yang melayani masyarakat atau pemustaka maka memerlukan sikap sopan-santun, sabar, dan tidak egois karena masyarakat pengguna jasa pelayanan berasal dari berbagai kalangan baik dari perbedaan tingkat ekonomi maupun tingkat status sosial.

\section{c. Kesediaan Melayani}

Pegawai harus profesional atau harus benar-benar dalam melayani pemustakanya, sebagaimana tugasnya yang harus siap selalu melayani pemustaka yang memang memerlukannya. 


\section{d. Pengetahuan dan Keahlian}

Supaya dapat melayani dengan baik, maka pegawai harus memiliki pengetahuan dan keahlian dalam bidang yang dikerjakannya. Misalnya petugas pelayanan yang memiliki tingkat pendidikan atau pelatihan tertentu maka jabatannya-pun harus yang sesuai dengan keahliannya.

\section{e. Tepat Waktu dan Janji}

Dalam pelayanan maka pegawai dalam melakukan tugasnya jika membuat janji dengan pemustaka harus diperhitungkan terlebih dahulu, apakah waktu dan janji tersebut bisa di tepati, misalnya mengadakan pertemuan dengan pemustaka dalam waktu kurun waktu 3 hari maka harus dapat terpenuhi.

\section{f. Kejujuran dan Kepercayaan}

Dalam melakukan pelayanan harus memiliki aspek kejujuran dalam segala hal, baik itu jujur dalam bentuk aturan, jujur dalam bentuk pembiayaan dan jujur dalam menyelesaikan pekerjaan tepat pada waktunya. Jika bersikap jujur maka petugas pelayanan dapat di percaya dari berbagai aspek misalnya dari segi perkataannya, sikapnya, dalam melakukan bekerja, dan lain-lain.

\section{g. Efesien}

Pelayanan kepada masyarakat atau pemustaka harus efesien dan efektif, karena pemustaka menuntut hal-hal tersebut. Sehingga dapat menghasilkan biaya murah, waktu singkat dan tepat, serta hasil dari pelayanan yang berkualitas. Oleh karena itu efesien dan efektif merupakan hal yang harus di wujudkan dan harus menjadi perhatian serius dalam melakukan pelayanan.

\section{h. Kepastian Hukum}

Jika hasil dari pelayanan yang dilakukan kepada pemustaka berupa suatu keputusan, maka harus memiliki kepastian hukum. Jika tidak memiliki kepastian hukum yang jelas maka akan berpengaruh kepada sikap masyarakat, misalnya dalam pelayanan mengurus surat-surat berharga jika ditemukan ketidakpastian 
hukum maka akan berpengaruh kepada kredibilitas lembaga atau pelayanan tersebut.

\section{i. Keterbukaan}

Setiap urusan atau kegiatan yang memperlakukan ijin, maka keterbukaan perlu di lakukan. Sikap keterbukaan itu akan berpengaruh pada kejelasan informasi kepada masyarakat atau pemustaka.

\section{j. Biaya}

Dalam pelayanan maka perlunya penentuan pembiayaan yang wajar. Oleh karena itu biaya harus disesuaikan dengan daya beli masyarakat, harus transparan, dan sesuai peraturan.

\section{k. Tidak Rasial}

Dalam melakukan pelayanan tidak boleh membeda-bedakan ras, suku, agama dan politik, jadi harus melayani secara merata.

\section{Kesederhanaan}

Prosedur atau tata cara pelayanan kepada para pemustaka harus dipermudah dan tidak berbelit-belit dalam pelaksanaannya.

\section{Pengertian Minat}

Menurut KBBI Minat adalah kecenderungan hati yang tinggi terhadap sesuatu; gairah; keinginan. ${ }^{3}$

Minat adalah suatu fungsi jiwa untuk dapat mencapai sesuatu yang merupakan kekuatan di dalam dan tampak di luar sebagai gerak - gerik. Dalam menjalankan fungsinya minat berhubungan erat dengan pikiran dan perasaan. Manusia memberi corak dan menentukan sesudah memilih dan mengambil keputusan. Perubahan minat memilih dan mengambil keputusan disebut keputusan kata hati. ${ }^{4}$

${ }^{3}$ Kementerian Pendidikan dan Kebudayaan Republik Indonesia, Kamus Besar Bahasa Indonesia (Badan Pengembangan dan Pembinaan Bahasa, 2016), https://kbbi.kemdikbud.go.id.

${ }^{4}$ Heri Purwanto, Pengantar Perilaku Manusia Untuk Keperawatan (Jakarta: EGC, 1998). 


\section{Pengertian Membaca}

Membaca adalah suatu proses yang dilakukan serta dipergunakan oleh pembaca untuk memperoleh pesan, yang hendak disampaikan oleh penulis melalui media kata-kata/bahasa tulis. Suatu proses yang menuntutagar kelompok kata yang merupakan suatu kesatuan akan terlihat alam suatu pandangan sekilas dan makna-makna kata secara individual akan dapat diketahui. Kalau hal ini tidak terpenuhi, pesan yang tersurat dan yang tersirat tidak akan tertangkap atau dipahami, dan proses membaca itu tidak terlaksana dengan baik. ${ }^{5}$

Dari segi linguistik, membaca adalah suatu proses penyandingan dan pembacaan sandi (a recording and decoding prosess), berlainan dengan membaca dan menulisyang justru melibatkan penyandingan (encoding). Sebuah aspek pembacaan sandi (decoding) adalah menghubungkan kata-kata tulis (written word) dengan makana bahasa lisan (oral language meaning) yang mencakup perubahan tulisan/cetakan memnjadi bunyi yang bermakana. ${ }^{6}$

Istilah-istilah linguistik decoding dan encoding tersebuat akan mudah dimengerti kalau dapat memahami bahwa bahasa (language) adalah sandi (code) yang direncanakan untuk membawa/menganding makana (meaning). Kalu kita menyimak pembicara, pada dasarnya kita men-decode (membaca sandi) makna ujaran tersebut. Apabila kita berbicara, pada dasarnya kita men-decode (menyandingkan) bunyi-bunyi bahasa untuk membuat/mengutarakan makna (meaning). Seperti juga halnya berbicara pada grafik, menulispun merupakan suatu proses penyandingan (encoding prosess), dan membaca sebagai suatu penafsiran atau interpretasi terhadap ujaran yang berada dalam bentuk tulisan adalah suatu proses pembacaan sandi (decoding prosess). Beberapa ahli lebih cenderung memakai istilah recording

${ }^{5}$ F.M. Hodgson, Learning Modern Languages (London: Routledge \& Kegan Paul, 1955), 43-44.

${ }^{6}$ Paul S. Anderson, Language Skills in Elementary Education (Macmillan, 1972), 209-210. 
(membaca) sebab pertama sekali lambing-lambang tertulis (written symbols) diubah menjadi bunyi, kemudian barulah sandi itu dibaca (are decoded). Menyimak dan membaca berhubungan erat karena keduanya merupakan alat untuk menerima komunikasi. Berbicara dan menulis berhubungan erat karena keduanya merupakan alat untuk mengutarakan makna, mengemukakan pendapat, mengekspresikan pesan. ${ }^{7}$

Di samping pengertian atau batasan yang telah diutarakan di atas, membaca pun dapat pula diartikan sebagai suatu metode yang kita pergunakan untuk berkomunikasi dengan diri kita sendiri dan kadang-kadang dengan orang lain-yaitu mengomunikasikan makna yang terkandung atau tersirat pada lambang-lambangtertulis. Bahkan, ada pula beberapa penulis yang seolah-seolah beranggapan bahwa "membaca" suatu kemampuan untuk melihat lambanglambang tertulis serta mengubah lambang-lambang tertulis tertulis tersebut melalui fonic (phonics = suatu metode pengajaran membaca, ucapan ejaan berdasarkan interpretasi fonetik terhadap ejaan biasa) menjadi/menuju membaca lisan (oral readig). Tingkatan hubungan antara makna yang hendak dikemukakan oleh penulis dan penafsiran atau interpretasi pembaca turut menentukan ketepatan membaca. Makna bacaan tidak terletak pada halaman tertulis, tetapi pada pikiran pembaca. Demikianlah, makna itu akan berubah karena setiap pembaca memiliki pengalaman yang berbeda-beda yang di pergunakan sebagai alat untuk menginterpretasikan kata-kata tersebut.

Secara singkat readingadalah meaning to and getting meaning fron printed or written material, memetik serta memahami arti atau makna yang terkandung di dalam bahan tertulis. ${ }^{8}$ Jelaskan bagi kita bahwa membaca adalah suatu proses yang bersangkut paut dengan bahasa. Oleh karena itu, para pelajar haruslah dibantu untuk menanggapi atau memberi respons terhadap lambang-

${ }^{7}$ Anderson, 4 .

${ }^{8}$ Mary Bonomo Finocchiaro dan Michael Bonomo, The Foreign Language Learner: A Guide for Teachers (Regents Pub. Co., 1973), 119. 
lambang visual yang menggambarkan tanda-tanda oditori yang sama yang yang telah mereka tanggapi sebelum itu. Menyimak dan berbicara haruslah selalu mendahului kegiatan membaca. Ketika membaca, kita membuat bunyi dalam kerongkongan kita. Kita membaca lebih cepat kalu kita tahu bagaimana cara mengatakan serta mengelompokkan bunyi-bunyi tersebut dan kalau kita tidak tertegun-tegun melakukannya. Oleh karena itu, sangat penting sekali diingat agar setiap kesulitan yang berkenaan dengan bunyi, urutan bunyi, intonasi, atau jeda haruslah dijelaskan sebelum para pelajar disuruh membaca dalam hati maupun lisan. ${ }^{9}$ Kesimpulan yang dapat di tarik dari pembicaraan di atas adalah bahwa" membaca ialah memahami pola-pola bahasa dari gambaran tertulisnya.". ${ }^{0}$

\section{Tujuan Membaca}

Tujuan utama dalam membaca adalam untuk mencari serta memperoleh informasi, mencakup isi, memahami makna bacaan. Makna, arti (meaning) eratsekali berhubungan dengan maksud tujuan, atau intensif kita dalam membaca. Berikut ini, kita kemukakan yang penting:

a. Membaca untuk menemukan atau mengetahui penemuanpenemuan yang telah dilakukan oleh tokoh; apa-apa yang telah dibuat oleh tokoh;apa yang telah terjadi pada tokoh khusus, atau untuk memecahkan masalah-masalah yang dibuat oleh tokoh. Membaca seperti ini disebut membaca untuk memperoleh perincian-perincian atau fakta-fakta (reading for details or facts).

b. Membaca untuk mengetahui mengapa hal itu merupakan topik yang baik dan menarik, masalah yang terdapat pada cerita, apa-apa yang dipelajari atau yang dialami tokoh untuk mencapai tujuannya. Membaca seperti ini disebut membasa untuk mendapat ide utama (reading for mein ideas).

\footnotetext{
${ }^{9}$ Finocchiaro dan Bonomo, 120.
}

${ }^{10}$ Robert Lado, Language Teaching: a scientific approach (Bombay-New Delhi: Tata McGraw-Hill, 1976), 132. 
c. Membaca untuk menemukan atau mengetahui apa yang terjadi pada setiap bagian cerita, apa yang terjadi mulamula pertama, kedua, dan ketiga/seterusnya -setiap tahap dibuat untuk memecahkan masalah, adegan-adegan dan kejadian, kejadian buat dramatisasi. Ini disebut membaca untuk mengetahui urutan atau susunan, organisasi cerita (reading for sequence or organization).

d. Membaca untuk menemukan serta mengetahui mengapa para tokoh merasakan seperti cara mereka itu, apa yang hendak diperlihatkan oleh pengarang pada para pembaca, mengapa para tokoh berubah, kualitas-kualitas yang dimiliki para tokoh yang membuat mereka berhasil atau gagal, ini disebut membaca untuk menyimpulkan (reading for inference).

e. Membaca untuk menemukan serta mengetahui apa-apa yang tidak biasa, tidak wajar mengenai seorang tokoh, apa yang lucu dalam cerita, atau apakah cerita itu benar atau tidak benar. Ini disebut membaca untuk mengelompokkan, membaca untuk mengklasifikasikan (reading for classify).

f. Membaca untuk menemukan apakah tokoh berhasil atau hidup dengan ukuran-ukuran tertentu, apakah kita ingin berbuat seperti yang diperbuat seperti tokoh, atau bekerja seperti para tokoh bekerja dalam cerita itu. Ini disebut membaca menilai, membaca mengevaluasi (reading to evaluate).

g. Membaca untuk menemukan bagaimana caranya tokoh berubah, bagaimana hidupnya berbeda dari kehidupan yang kita kenal, bagaimana ada cerita mempunyai persamaan, dan bagaimana tokoh menyerupai membaca. Ini membaca untuk memperbandingkan atau mempertenangkan (reading to compare or contrast). ${ }^{11}$

${ }^{11}$ Anderson, Language Skills in Elementary Education, 214. 


\section{Karakteristik Membaca Yang Menyenangkan}

Ibrahim Bafadal mengungkapkan bahwa paling tidak, ada sebelas ciri khas atau atau karakretistik membaca yang menyenangkan sehingga menghasilkan sebuah aktivitas yang bermakna dan bermanfaat bagi mahasiswa. Di antaranya adalah sebagai berikut:

a. Ada tujuan yang ditetapkan sebelum membaca.

b. Selama kegiatan membaca berlangsung, selalu menerapkan beberapa teknik dan ketrampilan membaca dengan harapan semakin lama semakin mahir.

c. Mampu menafsirkan berbagai peta, gambar, daftar, dan grafik, serta dapat menggunakan alat-alat penunjuk penelusuran buku-buku.

d. Seseorang yang membaca harus mempunyai latar belakang pemahaman sehingga dapat lebih mudah mengerti materi yang sedang dibacanya .

e. Seorang membaca yang baik membentuk sikap-sikap tertentu sebagai hasil pemahaman terhadap bahan yang sedang dibacanya.

f. Seorang meembaca yang baik selalu mengembangkan minat bacanya sebagaimana membina dan mengembangkan kemampuan bacanya.

g. Seorang pembaca yang baik tanpa tergantung pada orang lain. Ia selalu berusaha sepenuhnya menggunakan kemampuan sendiri.

h. Seorang pembaca yang baik harus bisa membaca dengan kritis, baik kritis dalam membaca dan memahami materi, faktual, terutama materi yang disusun untuk memengaruhi pembaca, maupun materi yang bersifat opini.

i. Seorang pembaca yang baik selalu melihat atau mengamati hubungan antara bahan yang sedang dibaca dengan masalah yang sedang dihadapi. 
j. Seorang pembaca yang baik selalu mengorganisasi konsep dari berbagai sumber dan membuat aplikasi praktis dari yang sedang dibacanya.

k. Seorang pembaca yang baik harus bisa membaca dengan penuh kenikmatan. Ia bisa duduk dengan santai dan memperoleh kesenangan dalam membacanya.

\section{Faktor-Faktor Kesiapan Membaca}

Kesiapan adalah suatu keadaan atau kondisi yang dapat meningkatkan keberhasilan membaca dan belajar. Dalam membina dan mengembangkan minat bacamahasiswa, pustakawan sangatperlu memperhatikan hal ini.

Ada sejumlah faktor yang turutmenentukan terhadap kesiapan mahasiswa dalam membaca dan belajar. Kesemuanya di kelompokkan menjadi empat hal, di antara kesiapan mental (mental readiness for reading), kesiapan fisik ( physical readiness for readng), kesiapan emosi (emotional readiness for reading), dan kesiapan pengalaman (experiential readiness for reading).

Terkait dengan kesiapan mental, dapat di jelaskanbahwa seseorang yang mentalnya cukup matang atau sehat maka akan terhindar dari gangguan jiwa, hatinya tenang, tenteram, dan bahagia. Ia pun dapat memanfaatkan segala potensi dan bakatnya dengan sangat maksimal. Namun, apabila mentalnya kurang sehat, akan timbul beberapa gejala, misalnya sering lupa, kemampuan berfikir menurun, sulit berkonsentrasi, dan lain sebagainya.

Kemudian, berhubungan dengan kesiapan fisik, ada beberapa faktor yang mempengaruhi keberhasilan membaca. Di antaranya, berhubungan dengan kapasitas atau kemampuan penglihatan dan pendengaran. Seseorang yang lemah penglihatannya tidak akanbisa melihat dengan jelas apa yang dibacanya. Sehingga, sebagai akibatnya, orang tersebut akan mengalami kesulitan membaca.

Sementara itu, berkenaan dengan kesiapan emosi, maka gangguan emosi dapat pula mempengaruhi keberhasilan membaca dan belajar. Seperti seorang anak yang memiliki sifat pemalu, 
terlalu penakut, menunjukkan kesulitan emosi. Pada akhirnya, kondisi itu menjadikannya kesulitan membaca dengan baik.

Dan terakhir, dan berkaitan dengan pengalaman. Maksudnya disini pernah atau tidaknya membaca, sering atau tidaknya membaca, luas atau tidaknya pengetahuan yang dimiliki, semua itu sangat mempengaruhi kesiapan membaca dan belajar mahasiswa. Sebagai contoh, mahasiswa yang memiliki latar belakang pengetahuan yang luas akan lebih cepat memahami bacaan daripada mahasiswayang kurang memiliki latar belakang pengetahuan.

\section{Usaha meningkatkan minat baca mahasiswa melalui pelayanan prima di perpustakaan perguruan tinggi}

\section{a. Upaya yang dilakukan oleh Pustakawan dalam penyediaan fasilitas di Perguruan Tinggi}

Salah satu tugas pustakawan dalam rangka memfungsikan perpustakaan sebagai pusat sumber belajar adalah membangkitkan rasa senang dan tertarik untuk membaca pada para mahasiswa. Sebab, apabila pada diri mahasiswa sudah muncul rasa senang membaca, ia akan senang membaca dan memanfaatkan perpustakaan dengan maksimal.

Ada beberapa upaya yang bisa dilakukan oleh pustakawan sekolah untuk membangkitkan rasa senang dan gairah membaca para mahasiswa.

Pertama, memperkenalkan buku-buku. Cara ini bisa dilakukan oleh pendidik pustakawan dengan jalan bekerja sama dengan pengajar mata kuliah. Jadi, biarkan para pengajar tersebut memanfaatkan koleksi pustaka yang dimiliki oleh perpustakaan sebagai bahan ajar. Dengan demikian, jika mahasiswatertarik, ia akan berkunjung ke perpustakaan.

Kedua, memperkenakkan riwayat hidup para tokoh. Pada cara ini, yang perlu ditekankan adalah sewaktu memperkenalkan, yaitu kegigihan tokoh-tokoh tersebut dalam hal membaca, belajar 
mandiri untuk menambah pengetahuan sehingga menjadi tokoh yang besar dan mashur.

Ketiga, memperkenalkan hasil-hasil karya para sastrawan. Sementaraitu, untuk cara ini, dapat dilakukan dengan memperkenalkan sastrawan-sastrawan Indonesia dengan berbagai mahakarya yang dihasilkannya. Dengan demikian, mahasiswabisa mengenaliberbagai karya mereka.

Keempat, dengan cara menyelenggarakan display dan pameran buku. Cara ini dilakukan dengan menempatkan dan menyusun buku-buku perpustakaan dengan posisi yang mencolok, sehingga membuat para mahasiswa tertarik untuk melihat. Itulah beberapa cara yang dapat dilakukan untuk meningkatkan minat baca para mahasiswa.

Cara lainnya adalah dengan memperbesar peranan pendidik dalam membangkitkan minat baca mahasiswa. Dalam hal ini, ada beberapa upaya yang dapat dilakukan. Pertama, perlu perbaikan metode belajar dan mengajar yang selama ini bersifat texsbooks centered kepada metode yang lebih membuka kemungkinan penggunaan bahan bacaan yang lebih luas dan bervariasi. Kedua, memberikan motivasi membaca kepada anak didik dengan pelaksanaan ulangan-ulangan. Ketiga, memberikan kebiasaan yang intensif sejak awal.

Keempat, melengkapi koleksi perpustakaan dengan bahanbahan bacaan yang menarik dan bermanfaat sesuai dengan kurikulum. Pengadaan bahan bacaan yang sesuai dengan selera (teste), kebutuhan (needs), dan tuntutan (demand) bisa menambah intensitas anak didik untuk berkunjung ke perpustakaan. Kelima, seorang pendidik bisa saja bekerja sama dengan pustakawan dalam mempromosikan cara mendayagunakan perpustakaan dengan benar, bahan -bahan apa saja yang ada di perpustakaan koleksi apa saja yang dianggap menarik dan baru, dan lain sebagainya. Keenam,pendidik bisa menanamkan kebiasaan membaca kepada mahasiswa melalui pemberian tugas-tugas membuat kliping, 
membuat karya ilmiah, ringkasan bab atau ringkasan buku-buku sastra, dan lain sebagainya.

\section{Penyediaan layanan Perpustakaan}

\section{a. Aplikasi IT Perpustakaan}

Seiring dengan perjalanan waktu, perkembangan information and technology (IT) semakin besar. Perkawinan antara perpustakaan dengan dunia IT dalam pelayanan yang diberikan kepada pengguna adalah sesuatu yang harus dilakukan. Maka dari itu, salah satu strategi pengembangan perpustakaan di era global sekarang perlu dikembangkan. Bagi yang sudah menggunakannya, berarti harus dilestarikan dan ditingkatkan, yaitu otomatisasi perpustakaan.

Seperti dijelaskan oleh Lasa $\mathrm{HS}^{12}$, untuk meningkatkan kinerja perpustakaan sekolah, kiranya perlu dipikirkan otomasi perpustakaan. Otomasi perpustakaan sebenarnya merupakan proses atau hasil penciptaan mesin swatindak atau swakendali dalam proses tersebut. Penerapan otomatimasi perpustakaan sekolah sebenarnya lebih rapat apabila disebut dengan teknologi informasi. Yaitu, teknologi elektronik yang digunakaan untuk pengumpulan, penyimpanan, pengolahan, dan pemanfaatan informasi. Dalam hal ini, tidak hanya terbatas pada pemanfaatan perangkat lunak atau perangkat keras, tetapi juga melibatkan unsur manusia.

Adapun pemanfaatan teknologi informasi untuk kegiatan perpustakaan yang dimiliki beberapa tujuan. Pertama, meringankan pekerjaan. Kedua, memudahkan dan memperlancar pelaksanaan tugas kepustakawanan. Ketiga, mempercepat temu kembali akan informasi. Keempat, memperlancar kerja sama informasi. Kelima, meningkatkan pelayanan informasi dan memanfaatkan teknologi informasi.

Teknologi informasi dapat di aplikasikan pada kegiatan pengadaan, inventarisasi, katalogisasi, sirkulasi, bibliografi, 215.

${ }^{12}$ Lasa Hs, Manajemen Perpustakaan Sekolah (Yogyakarta: Pinus, 2009), 
pengindeksan, dan penelusuran literature. Diakui bahwa pemanfaatan IT ini memerlukan biaya tinggi. Untuk itu, perlu dilakukan studi kelayakan, rancang bangun, implementasi, dan evaluasi. Contoh teknologi informasi dalam kegiatan perpustakaan yang telah terintegrasi di antaranya kegiatan inventarisasi, katalogisasi, penelusuran informasi, peminjaman, dan pengembalian buku yang tekah berjalan otomatis. Dalam sistem ini, pengguna dapat melakukan fotokopi sendiri. Mereka lebih dulu mengisikan kartu langganan untuk sejumlah tertentu, seperti voucer pada handphone. Para pemakai juga bisa bebas mem-browsing internet di sana. Mereka bisa men-download artikel tertentu atau mencetak pada public printer yang tersedia. Setelah selesai proses peminjaman tersebut, peminjam keluar melewati pintu ber-alarm yang berfungsi sebagai pengontrol dan mencatat pengunjung secara otomatis.

\section{Perpustakaan Digital}

Perubahan yang terjadi dari zaman ke zaman telah mengantarkan manusia ke era digital, suatu era yang sering kali menimbulkan pertanyaan, apakah kita masih hidup di masa kini atau telah hidup di masa yang akan datang. Teknologi komunikasi dan informasi atau teknologi telematika (ICT) telah diakui sebagai salah satu saranadan prasarana utuama untuk mengatasi masalahmasalah dunia. Perkembangan terkini dalam dunia teknologi dan informasi dan komunikasi mengalami perubahan yang signifikan, tidak terkecuali dengan perpustakaan. Perpustakaan telah berabadabad terkukung dalam koleksi tercetak, baik buku, jurnal, maupun majalah. Informasi yang disimpan dalam perpustakaan berupa catatan-cacatan. Sistem temu kembali informasinya pun belum terotomatisasi dan masih menggunakaan sistem manusia. Saat ini, zaman menuntut lain. Koleksi perpustakaan dituntutdalam bentuk digital, padahal sistem konvensional sudah meruah jumlahnya. Namun, jika pada era globalisasi ini tidak mengubah wajah konvensionalnya, nilai juang perpustakaan tersebut akan berkurang, atau mungkin suatu ketika harus siap di tinggalkan oleh penggunaanya. Suatu hal yang menarik pada era globalisasi 
ini perpustakaan dikatakan sebagai era digital. Maka, muncullah konsep digital library, digital library, yang koleksinya mengarah pada e-journal, e-book, dan sejenisnya.

Menurut Wiji Suwarno ${ }^{13}$, perpustakaan digital adalah perpustakaan yang mampu melayani penggunanya dengan segala kemudahan ${ }^{14}$. Perpustakaan adalah suatu sistem yang menyediakan suatu komunitas pengguna dengan akses terintregasi yang menjangkau keluasan informasi dan ilmu pengetahuan yang tersimpandan terorganisasi dangan baik. Menurut Brogman, sebagaimana dikutip Suwarno, lebih jelas definisi tentang perpustakaan digital muncul dari praktisi perpustakaan Digital Library Federation (DLF), ia menyatakann bahwa perpustakaan digital adalah organisasi yang menyediakan sumber dayamencakup mencakup staf ahli untuk memiliki struktur; penawaran akses intelektual untuk menginterpretasikan, mendistribusikan, memelihara integritas, dan koleksi dari waktu ke waktu sedemikian rupa; sehingga tersedia dan siap digunakaan oleh masyarakat.

\section{Pelayanan prima pemustaka}

Pelayanan prima yaitu melakukan pelayanan sebaik mungkin kepada para pemustaka atau pemustaka sehingga menimbulkan rasa yang puas. Secara umum tujuan pelayanan prima yaitu memberikan pelayanan sehingga bisa memenuhi dan memuaskan para pemustaka sehingga lembaga mendapatkan keuntungan yang maksimal. Manfaat dari pelayanan prima salah satunya untuk meningkatkan kualitas pelayanan lembaga ataupun pemerintah kepada para pemustaka atau masyarakat, serta dapat menjadi acuan untuk pengembangan penyusunan standar pelayanan. Standar pelayanan dapat diartikan sebagai tolak ukur atau patokan yang digunakan untuk melakukan pelayanan dan juga sebagai acuan untuk menilai kualitas suatu pelayanan. Pelayanan disebut prima jika pemustaka sudah merasa puas dan

\footnotetext{
${ }^{13}$ Wiji Suwarno, Pengetahuan Dasar Kepustakaan (Bogor: Ghalia Indonesia, 2010), 38-39.
} 
sesuai dengan harapan pemustaka.Dengan demikian maka dapat dipastikan bahwa pelayanan prima harus dilakukan sehingga dapat menumbuhkan minta baca mahasiswa di perpustakaan perguruan tinggi.

\section{Kesimpulan}

Pelayanan prima di perpustakaan merupakan hal yang sangat urgen dilakukan, karena keberhasilan perpustakaan sangat bergantung pada pemustakanya. Daya tarik perpustakaan tergantung pada pelayanan prima yang dilakukan oleh pihak perpustakaan. Pelayanan ini bisa berupa bentuk fisik yang disediakan dan pelayanan petugas perpustakaan.

Upaya yang bisa dilakukan oleh pustakawan sekolah untuk membangkitkan rasa senang dan gairah membaca para mahasiswa. Pertama, memperkenalkan buku-buku. Kedua, memperkenakkan riwayat hidup para tokoh. Ketiga, memperkenalkan hasil-hasil karya para sastrawan. Keempat, dengan cara menyelenggarakan display dan pameran buku.

Cara lainnya adalah dengan memperbesar peranan pendidik dalam membangkitkan minat baca mahasiswa. Dalam hal ini, ada beberapa upaya yang dapat dilakukan. Pertama, perlu perbaikan metode belajar dan mengajar yang selama ini bersifat texsbooks centered kepada metode yang lebih membuka kemungkinan penggunaan bahan bacaan yang lebih luas dan bervariasi. Kedua, memberikan motivasi membaca kepada anak didik dengan pelaksanaan ulangan-ulangan. Ketiga, memberikan kebiasaan yang intensif sejak awal.

Keempat, melengkapi koleksi perpustakaan dengan bahanbahan bacaan yang menarik dan bermanfaat sesuai dengan kurikulum. Pengadaan bahan bacaan yang sesuai dengan selera (teste), kebutuhan (needs), dan tuntutan (demand) bisa menambah intensitas anak didik untuk berkunjung ke perpustakaan. Kelima, seorang pendidik bisa saja bekerja sama dengan pustakawan dalam mempromosikan cara mendayagunakan perpustakaan dengan 
benar, bahan -bahan apa saja yang ada di perpustakaan koleksi apa saja yang dianggap menarik dan baru, dan lain sebagainya. Keenam, pendidik bisa menanamkan kebiasaan membaca kepada mahasiswa melalui pemberian tugas-tugas membuat kliping, membuat karya ilmiah, ringkasan bab atau ringkasan buku-buku sastra, dan lain sebagainya. 


\section{DAFTAR PUSTAKA}

Anderson, Paul S. Language Skills in Elementary Education. Macmillan, 1972.

Finocchiaro, Mary Bonomo, dan Michael Bonomo. The Foreign Language Learner: A Guide for Teachers. Regents Pub. Co., 1973.

Hodgson, F.M. Learning Modern Languages. London: Routledge \& Kegan Paul, 1955.

Kementerian Pendidikan dan Kebudayaan Republik Indonesia. Kamus Besar Bahasa Indonesia. Badan Pengembangan dan Pembinaan Bahasa, 2016. https://kbbi.kemdikbud.go.id.

Lado, Robert. Language Teaching : a scientific approach. BombayNew Delhi: Tata McGraw-Hill, 1976.

Lasa Hs. Manajemen Perpustakaan Sekolah. Yogyakarta: Pinus, 2009.

Prastowo, Andi. Manajemen Perpustakaan Sekolah Profesional. Yogyakarta: Diva Press, 2012.

Purwanto, Heri. Pengantar Perilaku Manusia Untuk Keperawatan. Jakarta: EGC, 1998.

Rahmayanty, Nina. Manajemen Pelayanan Prima. Yogyakarta: Graha Ilmu, 2013.

Suwarno, Wiji. Pengetahuan Dasar Kepustakaan. Bogor: Ghalia Indonesia, 2010. 